\title{
Problémamegoldó ápolási-gondozási modell Parkinson-kórban
}

\author{
Csóka Mária ${ }^{1}$ - Molnár Sándorné ${ }^{2,3}$ - Kellős Éva ${ }^{4,5}$ - Domján Gyula dr. ${ }^{5}$ \\ ${ }^{1}$ Semmelweis Egyetem, Egészségtudományi Kar, \\ Alkalmazott Egészségtudományi Intézet, Ápolástan Tanszék, Budapest \\ ${ }^{2}$ Országos Egészségbiztosítási Pénztár, Budapest \\ ${ }^{3}$ Semmelweis Egyetem, Doktori Iskola, Budapest \\ ${ }^{4}$ Emberi Erőforrások Minisztériuma, Egészségügyi Ágazati Humánerőforrás-stratégiai Főosztály, Budapest \\ ${ }^{5}$ Semmelweis Egyetem, Egészségtudományi Kar, Egészségfejlesztési és Klinikai Módszertani Intézet, Budapest
}

Bevezetés: A Parkinson-kór becslések szerint több mint 6,3 millió embert érint a világon. Ezek többségének és hozzátartozóinak egyedül kell megbirkóznia a gyógyszerszint-ingadozások motoros következményeivel és az anti-Parkinson-gyógyszerek pszichotikus mellékhatásaival. Nemritkán még az ellátók számára is gondot jelent a fellépő problémák helyes értelmezése és menedzselése. Célkitüzés: A szerzők célul tűzték ki a Parkinson-kóros betegek igényeinek rendszerezett áttekintését és ezek alapján egy bizonyítékokra épülő komplex Parkinson ápolási-gondozási modell kidolgozását. Módszer: A jelentkező igények meghatározásánál a szerzők egy idős, 28 éve Parkinson-kóros beteg többéves megfigyelése során szerzett tapasztalatokra támaszkodtak. A Parkinson ápolási-gondozási modellben a betegség specifikumaihoz illeszkedő multidiszciplináris ellátási keretrendszert fogalmaztak meg, amely meghaladja a standard ápolási modellek korlátait. Eredmények: A modell tartalmazza az egyes betegek köré szerveződő kooperatív problémamegoldási folyamat leírását és a betegek lehetséges problémáinak individualizált megoldására vonatkozó javaslatokat. Következtetések: A modell alkalmazása javíthat a Parkinson-kóros betegek életminőségén és megkönnyítheti az érintett családok életét, feltéve, ha a családok tisztában vannak az új ellátási forma előnyeivel. Orv. Hetil., $2016,157(22), 855-868$.

Kulcsszavak: Parkinson-kór, Parkinson-szindróma, életminőség, Parkinson ápolási-gondozási modell, ápolási-gondozási terv, betegedukáció

\section{Problem solving care models of Parkinson's disease}

Introduction: Parkinson's disease affects more than 6,3 million people worldwide. Most patients and relatives are left alone to struggle with the symptoms associated with fluctuations in drug levels and the psychotic side effects of the anti-Parkinson's medications. Moreover, quite often even health providers may find difficult to interpret and manage the problems that have been encountered. Aim: The aims of the authors were to analyze systematically the biopsychosocial needs of Parkinson's patients, and to develop a complex, evidence-based Parkinson's-nursing-care model. Method: Patients' needs were assessed based on an observational study involving an old patient with Parkinson's disease for more than 28 years. The model has been specified as a multidisciplinary care framework adapted to the special characteristics of Parkinson's disease which transcends the limitations of different standard nursing models. Results: The elaborated model contains a detailed description of cooperative problem solving, which is organized around individual patients along with recommendations for addressing various potential problems that might be encountered. Conclusions: Implementation of the presented model can improve the life quality of Parkinson's patients and can facilitate the life of affected families provided that these families are well aware about the potential benefits of the novel care delivery system.

Keywords: Parkinson's diseae, Parkinson's syndrome, quality of life, Parkinson's nursing-care model, nursing care plan, patient education

Csóka, M., Molnár, S., Kellös, É., Domján, Gy. [Problem solving care models of Parkinson's disease]. Orv. Hetil., 2016, 157(22), 855-868.

(Beérkezett: 2016. március 1.; elfogadva: 2016. március 31.) 


\section{Rövidítések}

$\mathrm{ADL}=$ (activities of daily living) mindennapi tevékenység; EPDA $=($ European Parkinson's Disease Association $)$ Európai Parkinson-kór Szövetség; IPMD = (International Parkinson and Movement Disorder Society) Nemzetközi Parkinson és Mozgászavar Társaság; MDS $=($ Movement Disorder Society $)$ Mozgászavar Társaság; PÁGM = Parkinson ápolási-gondozási modell; PK = Parkinson-kór

A remegés, meglassultság, izommerevség és testtartási instabilitás tünetegyüttest Pápai Páriz Ferenc írta le elsőként 1690-ben, a betegség mégis James Parkinson mûve alapján került az orvosi köztudatba [1]. James Parkinson (1755-1824) angol polihisztor 1817-ben publikálta az „An essay on the shaking palsy” (Egy tanulmány a remegô bénulásról) címú mûvét, amelyben remegve bénulás, reszkető („Paralysis agitans”), rázó bénulásként írta le a kórképet. Később, a sclerosis multiplex első leírója, a modern neurológia atyja, a „neurózisok Napóleonjaként" emlegetett francia, Jean-Martin Charcot (18251893 ) a betegséget Parkinson-kórnak nevezte el. Bár a Parkinson-kór (PK) etiológiáját a mai napig nem tudjuk pontosan definiálni, számos kutatás bizonyítja, hogy nem csupán egy mozgászavarral, hanem az idegrendszer csaknem egészét érintő progresszív, neurodegeneratív betegséggel állunk szemben. Egyelöre neuropatológiai, biokémiai és tünettani szempontból tudjuk jellemezni. A klasszikus értelmezés szerint patológiai hátterében a kóros fehérjeképződés következtében a középagyban található fekete mag (substantia nigra) dopamin ingerületátvivő anyagot termelő sejtjeinek egyre fokozódó pusztulása, továbbá Lewy-testek (zárványok) megjelenése áll (1912-ben írta le Friedrich H. Lewy), ami a bazális ganglionok neurotranszmitter-rendszerének felborulásához vezet. A degeneratív betegségek körében az alfa-synucleinopathiák közé soroljuk, amelynek legjellemzőbb biokémiai alapja a dopamin-acetilkolin egyensúly felborulása, de sérül a glutamaterg és a noradrenerg rendszer is. A modern, Braak-féle neuropatológiai értelmezés szerint a központi idegrendszer egyre kiterjedtebb múködészavaráról van szó, amelyben a substantia nigra degenerációját megelőzi a nem motoros tünetekért felelős idegsejtek károsodása, és a motoros tünetek csak azért „késnek”, mert a striatum 70-80\%-os dopaminhiányt képes kompenzálni. Ennek tulajdonítható az a több évtizedes preklinikus állapot, amely megelőzi a betegséget. Az utóbbi évek kutatásai megdöntötték azt a hagyományos nézetet, miszerint a PK elsődlegesen a substantia nigrában található dopaminerg neuronok betegsége. A Lewy-elváltozások nemcsak a központi, hanem a perifériás idegrendszert is érintik, és Braak azt is felveti, hogy a laesiók már a PK korai szakaszában megfigyelhetók az enterikus neuronokban, még mielőtt a substantia nigrában található neuronokban létrejönne az elváltozás. Etiológiailag három nagy csoport különböztethetô meg: amennyiben ismeretlen a kiváltó ok, akkor primer vagy idiopathiás
PK-ról, ha pedig ismert, akkor szekunder parkinsonizmusról vagy Parkinson-szindrómáról beszélünk, amely az idegsejt-károsodás típusa alapján lehet másodlagos parkinsonizmus vagy Parkinson-plusz-szindróma [2-7].

A PK mára az Alzheimer-kór után a második leggyakoribb kórkép, becslések szerint több mint 6,3 millió embert érint a világon, Európában ez a szám jelenleg 1,4 millióra, Magyarországon körülbelül 20-30 ezerre tehető, és 2030-ra a PK-betegszám kétszeresével számolhatunk. Minden jel szerint a degeneratív idegrendszeri betegségek idővel a halálozási lista élére kerülnek, ami betegre, társadalomra nézve egyaránt aggasztó. Az európai betegszervezet - European Parkinson's Disease Association (EPDA) - 1992-es megalakulása óta ernyőintézményként 26 európai ország betegszervezeteit összefogva célul tűzte ki a PK-betegek és családtagjaik helyzetének javítását. Ennek fontosságát mutatja, hogy 1993 óta a Nemzetközi Parkinson-kór Napot világszerte James Parkinson születésnapján, április 1l-én tartják, a betegség jelképe a piros tulipán. A Delta Magyar Parkinson Egyesület 1998-as megalakulását követően 2006-ban csatlakozott az EPDA-hoz, és azóta hazánk is országos rendezvényeket tart a világnapon. Az EPDA 1997-ben kiadott chartáját Magyarország 2009 májusában írta alá, amelynek célkitüzései, hogy minden beteg jusson el PK-val foglalkozó specialistához, kapjon korai és pontos diagnózist, részesüljön szociális támogatásban, folyamatos gondozásban, és aktív részese lehessen betegsége kezelésének. 2013-ban Sydneyben bejelentették, hogy a legnagyobb nemzetközi Mozgászavar Társaság (Movement Disorder Society - MDS) a nevét Nemzetközi Parkinson és Mozgászavar Társaságra (International Parkinson and Movement Disorder Society) változtatta. A több mint 4500 klinikus, kutató és más egészségügyi szakember a betegellátás, az oktatás és a kutatás fejlesztésén dolgozik [8].

A jellegzetes tünetekről elmondható, hogy általában 50-60 éves korban jelentkeznek, de nem ritka 30-40 éves korban sem. A négy motoros alaptünet a bradykinesia/hypokinesia, rigor, nyugalmi tremor és előrehaladott betegségben a tartási instabilitás. A bradykinesia nemcsak meglassultságot, hanem a mozgások amplitúdójának csökkenését is jelenti (hypokinesis). A tévhittel ellentétben nem a tremor az első tünet, és nem jelentkezik mindenkinél. A PK tüneteit az 1. táblázatban részletezzük.

A tünetek alapján a betegség három (tremor domináns, rigid-akinetikus, kevert) klinikai altípusát és három nagy stádiumát (preklinikus állapot, mézeshetek-időszak, késői PK) különítjük el. A diagnózist jelenleg csak szövettani vizsgálattal lehet teljes biztonsággal kimondani, nem ismert olyan laboratóriumi vagy képalkotó vizsgálat, ami megbízható eredményt adna [2,9]. A vizsgálatok inkább a PK-hoz hasonló tünetekkel járó egyéb megbetegedések kizárására alkalmasak. Jól megválasztott kezeléssel a tünetek akár 10-20 évig is hatásosan kezelhetőek, sőt a mozgásképesség is javítható $[2,10-16]$. 
1. táblázat |A Parkinson-kór motoros és nem motoros tünetei

\begin{tabular}{l} 
Motoros tünetek \\
\hline Végtagmerevség (rigor): kóros izomtónus-fokozódás, az agonista és \\
antagonista izmok tónusa egyidejűleg növekszik, fájdalmas \\
izomgörcsök lépnek fel. A végtagok passzív mozgatásakor folyamatos \\
ellenállást, rigiditást érzünk (ólomcsőtünet), és csak kis idő elteltével \\
válik lehetővé a további mozgás (fogaskeréktünet), gyakran féloldali, \\
aszimmetrikus, főleg a betegség kezdetekor, majd átterjed mindkét \\
oldalra, de az aszimmetria mindvégig megmarad.
\end{tabular}

Végtagügyetlenség.

Járászavar: a járás csoszogó, apró léptûvé válik (marche à petit pas). Indulási és felállási nehézség, toporgás (start hesitation) után a járás felgyorsulhat, amit a beteg nem tud megállítani. Megforduláskor vagy szúk helyen elhaladáskor lefagyás, teljes leállás is megjelenhet (freezing of gait). Ezek az úgynevezett letapadási jelenségek bármikor felléphetnek, éjszaka nem tud megfordulni az ágyában, felálláskor nem képes súlypontját megfelelően előrevinni, majd onnan felegyenesedni. A lassú járástempó mellett a karok együttmozgása (synkinesis) is csökken, a karlengetés elmarad (aszimmetria). Megfordulás általában több lépésben lehetséges.

Bradykinesia: mozgásmeglassultság.

Hypokinesia: alacsonyabb amplitúdójú mozgáskivitelezés.

Akinesia: az akaratlagos mozgásszabályozás megszúnése (tényleges bénulás nélküli mozgásképtelenség).

Camptocornia: Extrém görnyedt testtartás, amelyet a tartási instabilitás, a bradykinesia és a rigor együttesen okoz.

Nem motoros tünetek

Szenzoros rendellenességek: csökkent szaglási, ízérzékelési képesség.

Fáradékonyság.

Gyomor-bél rendellenességek, emésztési problémák, székrekedés.

Szexuális problémák (késői fázisban megjelenő tünet).

REM (rapid eye movements) magatartászavar: normálisan REMfázisban a szem- és a légzőizomzat kivételével a legtöbb izomzat tónusa csökken, ilyenkor álmodunk, RBD (REM behavior disorder) esetén viszont az izomzat tónusának gátlása nem valósul meg, ezért alvás közben a betegnél mozgások vagy felkiáltások alakulnak ki. A nyugtalan láb szindróma ( $R L S=$ restless legs syndrome): szúró, viszkető, égető fájdalom a csontokban és a vénákban, általában az esti órákban, pihenéskor, lefekvéskor jelentkező vagy erősödő tünet.

Hypomimia: a mimikai izmok csökkent működésére vezethető vissza, a beteg arca kifejezéstelen, pókerarcnak (Parkinson-maszk) is nevezhetjük.

Micrographia: kézíráskor kifejezetten csökkent betüméret, olvashatatlan lesz az írás, a betű elvész a sor végére.

Beszédzavar: gyakran monoton, néha hadaró a beszéd, nehezen érthető, beszédindítási nehézség.

Nyelészavar: a betegek keveset és gyengén nyelnek (a késői fázisban jelenik meg).

Testtartási instabilitás és elesések: azoknak a tartási reflexeknek a károsodása, amelyek minden körülmény között (például járás, közlekedési jármű, mozgólépcső használata) biztosítják az egyensúly megtartását. Ezek a reflexek már a betegség elején károsodnak, előrehaladott stádiumban teljes mértékben kieshetnek, emiatt könnyen eleshet a beteg.

Remegés (tremor): fóleg nyugalomban, ami a kézen és az ajkakon a legkifejezettebb. Gyakran nevezik pilulasodró, pénzszámláló mozgásnak, amikor a betegek ujjaikkal olyan mozgást végeznek, mint amikor pénzről beszélünk. Cselekvéskor teljesen megszúnik vagy legalábbis enyhül, nem ez az első tünet, és nem jelentkezik mindenkinél.

\section{Parkinson ápolási-gondozási modell (PÁGM)}

A PK hallatán a legtöbb embernek csak egy remegő, csoszogó, hajlott hátú idôs ember jut az eszébe, de hogy valójában mekkora kihívás ezzel a betegséggel együtt
Fokozott nappali aluszékonyság: az alvászavarral vagy

gyógyszermellékhatással összefüggő cirkadián ritmus felborulásának következménye.

Vegetatív idegrendszeri müködészavar: fokozott nyálképzés, nyálömlés (drooling), fokozott verítékezés, a faggyúmirigyek túlmúködése miatt seborrheás bőr.

Orthostaticus hypotonia: hirtelen vérnyomásesés, megszédülés, esetleg ájulás (késői fázisban megjelenő tünet).

Urológiai rendellenességek: vizelettartási zavar, inkontinencia (késői fázisban megjelenő tünet).

Neuropszichiátriai rendellenességek: szorongás, depresszió, pánikzavar, ingerlékenység, gondolkodási problémák (bradyphrenia). Tudatzavar, hallucináció, agitáció (késői fázisban megjelenő tünet).

Szellemi leépülés (dementia), amit a betegek szerencsére nem élnek meg (késői fázisban megjelenő tünet). 

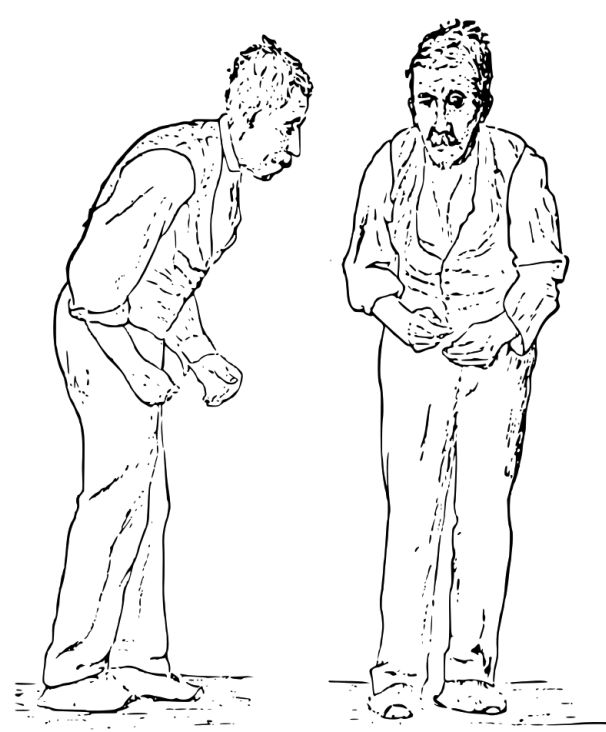

1. ábra

Parkinson-kórban szenvedő betegek

William Richard Gowers ideggyógyász rajza (1886)

(Forrás: https://hu.wikipedia.org/wiki/Parkinson$\mathrm{k} \% \mathrm{C} 3 \% \mathrm{~B} 3 \mathrm{r}$ )

szerúbb diagnosztikus és terápiás eljárásokról számolnak be, a PK-betegek többségének és hozzátartozóinak nap mint nap egyedül kell megbirkóznia a motoros és nem motoros tünetekkel. Az alkalmazkodás kérdése akkor vetődik fel különösen élesen, amikor a betegnek egyszerre kell elviselnie a gyógyszerszint-ingadozás következményeként kialakuló csökkent mozgásteljesítményt, és az anti-Parkinson-gyógyszerek mellékhatásaként jelentkező izgatottságot, napokig tartó ébrenlétet, hallucinációkat vagy a minden előzmény nélküli ájulást. Nemritkán még az ellátók számára is gondot jelent ezeknek a problémáknak a helyes értelmezése és menedzselése, ezért célul tűztük ki a tünetek neuropatológiai és biokémiai hátterére alapozott, evidenciákra épülő komplex Parkinson ápolási-gondozási modell (PÁGM) kidolgozását, amelyben a betegségközpontú megközelítést a betegközpontú szemlélet váltja fel, ezáltal a beteg mint individuum kerül a középpontba, és köré szerveződik az ellátás. Legfőbb célunk segítség nyújtása a beteg gondozóinak a hirtelen fellépő problémák adekvát megoldására.

$\mathrm{Az}$ ápolástudomány számos ápolási modellt kínál, amelyek alapvetó értékei a holizmus, humanizmus, autonómia és a partnerség. A PK-betegek gondozása azonban nem oldható meg egyetlen standard modell alkalmazásával, a betegség természetéből adódó progrediáló állapotváltozás kézben tartása az egészségügyi és szociális szakemberektôl, valamint a családtól és a segítóktől egyaránt szoros együttmúködést és folyamatos problémamegoldást feltételez. A jelentkező igények meghatározásánál egy idős, 28 éve PK-beteg többéves megfigyelése során szerzett tapasztalatokra támaszkodtunk, és a PÁGM-ben a betegség specifikumaihoz illeszkedő multidiszciplináris ellátási keretrendszert fogalmaztunk meg, amely meghaladja a standard ápolási modellek korlátait. A modell tényszerúen ismerteti a beteg szükségleteit, problémáit, és azt is, hogyan befolyásolják ezek a Parkinson-beteg és családja életét. A modell kidolgozásához a megfigyelés és a retrospektív dokumentumelemzés módszerét választottuk.

A betegség okozta elváltozások sora pszichés és szociális feszültségek kialakulásához vezet, amelynek leküzdésében az egészségügyi személyzetnek és a család támogató magatartásának óriási szerepe van. Számunkra fontos annak megfogalmazása, hogy ki mit tehet a beteg függetlenségének és személyi integritásának megőrzésében, és hogyan vonható be a család ebbe a folyamatba, ami arra hívja fel a figyelmet, hogy a beteg-egészségügyi team kapcsolaton túl a beteg-egészségügyi team-család viszonyát sem szabad kifelejteni modellünkből.

A PK-betegek komplex ellátásához két szükségletelméleti (Virginia Henderson, 1964 és Faye Abdellah, 1960), egy eredményelméleti (Callista Roy, 1975) és egy rendszerelméleti (Betty Neuman, 1972) modellt vettünk alapul (2. táblázat). Ezek az első modellek hagyományokon, empírián és a korai ápolói teóriák hatására született elméleteken alapultak, céljuk iránymutatás nyújtása volt a gyakorlati helyzetek megoldására [17]. Az alapvetô cél azóta sem változott, csak kiegészült az ápolási gyakorlatban, ápolásvezetésben és az ápolásoktatásban alkalmazható irányelvek felállításával, amely a társtudományok (orvostudomány, pszichológia, szociológia, pedagógia) kutatási eredményein alapul. Ma már a gyakorlati fejlődés alapvető követelménye, hogy az ápolás is evidenciákra épüljön (evidence-based nursing) és önálló tudománnyá fejlódjön. Ezt segítik elő az ápolási modellek, amelyek paradigmái (nézetei) fogalmi keretet nyújtanak a különböző elméleteknek, rámutatnak az elméletek fogalmainak összefüggéseire és koncepciókat alkotnak a gyakorlati munkára, ezáltal kutathatóvá válnak.

Faye Abdellah 1960-ban a szükségletek alapján 21 ápolási problémát fogalmazott meg, amelyek az ápolás célját képezik, és az ápolói munkát mint problémamegoldó és döntéshozó tevékenységnek tekinti. Abdellah szerint az ápolás metaparadigmái: az ember, egészség, környezet, ápolás.

Virginia Henderson 1964-ben megjelent modelljében az ápolást támogató tényezőként, az ápolót mint független szakembert írja le, nevéhez füződik a 14 alapvető emberi szükséglet megfogalmazása, amely máig meghatározza az ápolás alapját.

Betty Neuman és Callista Roy ma is élő ápolásteoretikusok. Neuman 1972-ben tette közzé holisztikus rendszermodelljét, amelynek középpontjába az ember fiziológiai, pszichológiai, szociokulturális és fejlesztési szempontjait helyezte. Roy 1975-ben megjelent adaptációs ápoláselméletében az emberi szükségletek négy fó csoportját alkotta meg (fiziológiai, énkép, szerepek, kölcsönös függés), és az alkalmazkodásra helyezte a hangsúlyt, célja a beteg adaptációjának előmozdítása. 


\begin{tabular}{|c|c|c|c|}
\hline $\begin{array}{l}\text { Faye Glenn Abdellah (1919-) } \\
\text { modellje (1960) }\end{array}$ & $\begin{array}{l}\text { Virginia Henderson (1897-1996) } \\
\text { modellje (1964) }\end{array}$ & $\begin{array}{l}\text { Betty Neuman (1924-) modellje } \\
(1972)\end{array}$ & $\begin{array}{l}\text { Callista Roy (1939-) modellje } \\
(1975)\end{array}$ \\
\hline 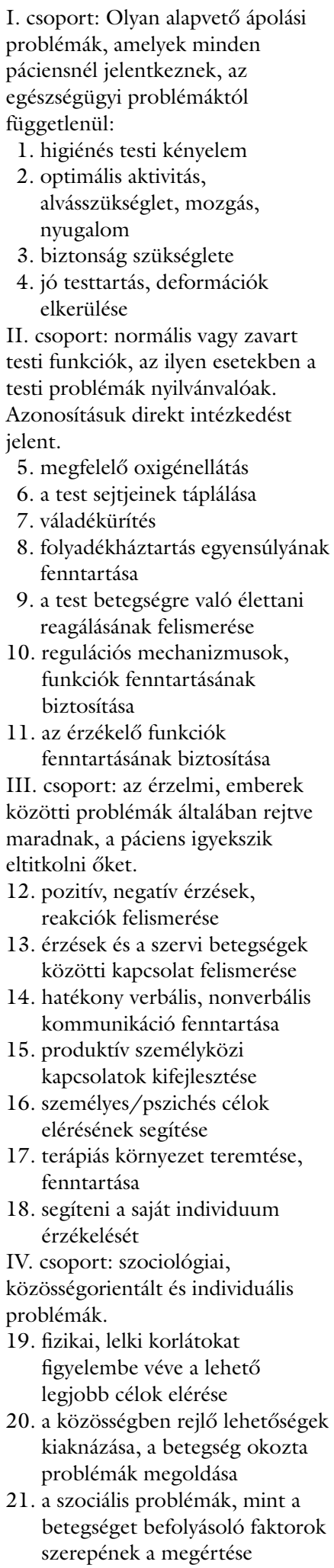 & $\begin{array}{l}\text { A } 14 \text { alapszülsséglet Henderson } \\
\text { szerint: } \\
\text { 1. A normális légzés. } \\
\text { 2. A kielégítő evés és ivás. } \\
\text { 3. A szervezet salakanyagainak } \\
\text { kiürítése. } \\
\text { 4. A mozgás és a kívánt } \\
\text { testhelyzetek fölvétele. } \\
\text { 5. Az alvás és a pihenés. } \\
\text { 6. A megfelelő ruházat. } \\
\text { 7. A testhőmérséklet normális } \\
\text { határok közötti fenntartása. } \\
\text { 8. A test tisztán tartása. } \\
\text { 9. A környezetben rejlő } \\
\text { veszélyek elkerülése. } \\
\text { 10. A többi emberrel való } \\
\text { kapcsolattartás. } \\
\text { 11. A vallás gyakorlása. } \\
\text { 12. A sikerélményt nyújtó } \\
\text { munkavégzés. } \\
\text { 13. A játék. } \\
\text { 14. A tanulás. }\end{array}$ & $\begin{array}{l}\text { Az ápolás gyakorlatának } \\
\text { rendszermodellje a megterhelés } \\
\text { csökkentését célozza meg. Az } \\
\text { ápolási tevékenység három szinten } \\
\text { hat: elsődleges, másodlagos és } \\
\text { harmadlagos szinten. A modell } \\
\text { célja egy holisztikus fiziológiai, } \\
\text { pszichológiai, szociokulturális } \\
\text { szemléletmód kialakítása az } \\
\text { emberi lét különböző fejlettségi } \\
\text { fokainak figyelembevételével. } \\
\text { A rendszer két fö összetevőból áll: } \\
\text { a környezetből érkező stresszorok } \\
\text { és az egyén általi stresszreakció. } \\
\text { A stresszorok attól függően, hogy } \\
\text { honnan erednek, lehetnek: } \\
\text { 1. Intraperszonális, az egyén } \\
\text { jelleméből, attitűdjéből, } \\
\text { magatartásából származók. } \\
\text { 2. Interperszonális, a személyek } \\
\text { közötti kapcsolatból } \\
\text { származók. } \\
\text { 3. Extraperszonális, a társadalom } \\
\text { nagyobb területéról származók. }\end{array}$ & $\begin{array}{l}\text { Négy adaptációs módot (élettani, } \\
\text { pszichológiai, szociológiai és } \\
\text { függetlenségi mód) egyesítő } \\
\text { adaptációs modell. Roy szerint az } \\
\text { emberi szükségleteknek } 4 \text { fő } \\
\text { csoportja van: } \\
\text { 1. Fiziológiai (élettani), amelyhez } \\
\text { tartozik a munka és a pihenés, } \\
\text { a táplálkozás, az ürítés, } \\
\text { a folyadékháztartás, a keringés, } \\
\text { a hőszabályozás és endokrin } \\
\text { múködés. } \\
\text { 2. Énkép (önkép), amely az egyén } \\
\text { önmagáról alkotott } \\
\text { elképzeléseinek összessége. } \\
\text { 3. Szerepek: Roy a társadalmi } \\
\text { életben betöltött szerepeket } \\
\text { szerepfával szimbolizálja, } \\
\text { ahol a törzs hosszú évtizedeket } \\
\text { meghatározó vagy soha nem } \\
\text { változó szerepeket takar } \\
\text { (például nem, valaki } \\
\text { gyerekének vagy anyának } \\
\text { lenni). } \\
\text { 4. Kölcsönös függés: A függőség és } \\
\text { egyensúlyi állapot megtalálása. }\end{array}$ \\
\hline
\end{tabular}

Látható, hogy az egyes modellek hasonlóak, s bár különböző szempontokat hangsúlyoznak, az emberi szükségletek és a személyközi kapcsolatok minden ápolásteo- retikusnál megjelennek valamilyen kontextusban. Mindenki által jól ismert Maslow 1950-es években megalkotott ötlépcsős emberi szükségletek hierarchiája, a 


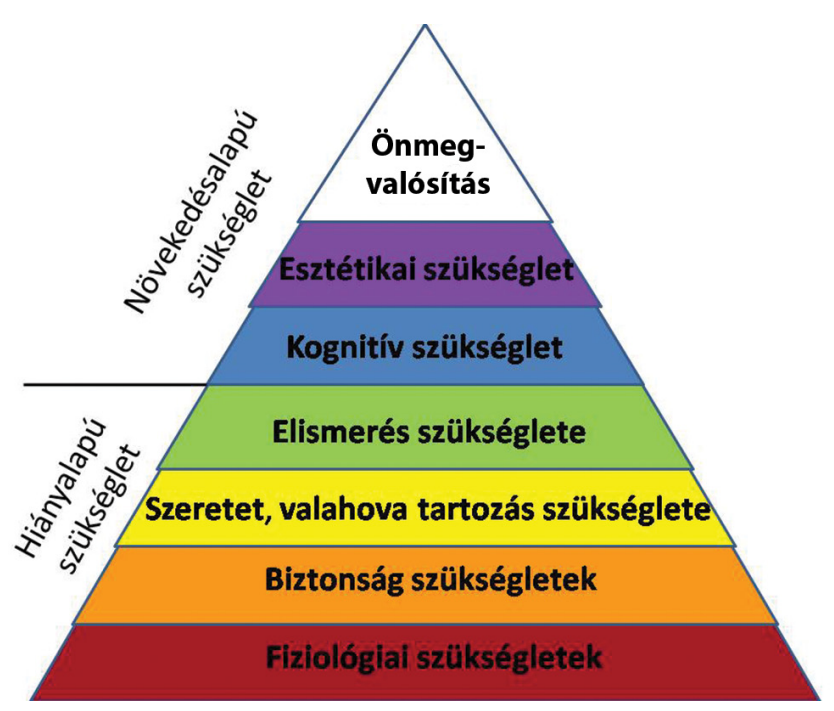

2. ábra határozható legyen, és konkrét tartalmat kapjon a mindennapi élethez szükséges tevékenységekre (activities of daily living - $\mathrm{ADL}$ ) is.

Mint ahogy nincs két egyforma személyiség, úgy nincs két egyforma PK-beteg sem. Mindenki másképpen éli meg a betegséget, ráadásul a tünetek és a gyógyszerekre adott válaszreakciók is eltéróek lehetnek, ezért a Parkinson-beteg gondozójának először is meg kell értenie a betegség természetét, hogy minden helyzetben adekvát segítséget tudjon nyújtani. Teljes mértékben tisztában kell lenni a gondozott személy szükségleteivel, a betegség progressziójával, és fel kell készülni a változásokra. Ismerni kell a gondozott személy által szedett gyógyszereket és azok hatásait, valamint a gyógyszeralkalmazás szabályait. Tudni kell, hogy melyiket mire kapja, milyen mellékhatásokra lehet számítani. Időseknél már majdnem minden gyógyszernél számolhatunk valamilyen kellemetlen mellékhatással, ami egy újabb betegség oka lehet. Fontos a gyógyszerek pontos szedésének ellenőrzése, és a folyamatos konzultáció a gondozott személy kezelöorvosával. A beteg és a gondozó számára egyaránt fontos a betegséggel kapcsolatos fogalmak megtanulása: a jó és rossz mozgásteljesítményú állapot változása (on-off fluktuáció), lefagyás (freezing), mozgásindítási nehezítettség (hezitáció), túlmozgások (dyskinesia) és fájdalmas izomgörccsel járó kényszertartás (dystonia) kialakulása, hirtelen vérnyomásesés, megszédülés, collapsus. Ezek ijesztőek lehetnek azok számára, akik nem készültek fel rá, ezért fontos az edukáció. Fel kell ismerni a tünetek változásait (izommerevség, lelassultság), amelyek a gyógyszerhatástartam rövidülését jelezhetik, ilyenkor türelemmel kell viselni, hogy a betegnek rosszabb napja van.

A továbbiakban egy idős beteg 3 éves intervallumban történő közvetlen megfigyelésének tapasztalatai, valamint az átadófüzet adatai alapján mutatjuk be modellünket.

\section{Esettanulmány}

A 89 éves nóbeteg 60 éves korában vált özveggyé, ennek ellenére nem akart a családjához költözni. Férje halálát követóen, 1987-ben PK-t diagnosztizáltak nála, ami napi $10 \mathrm{mg}$ selegilin tablettával 15 évig egyensúlyban volt, majd járása egyre bizonytalanabbá vált, többször elesett az utcán, ekkor gyermekei úgy döntöttek, hogy biztonsága érdekében a lakásra hozatják az ebédet és a szociális gondozói hálózat segítségével megszervezik felügyeletét. 2012-ben otthoni elesés következtében jobb csípőtáji (pertrochanter-) törést szenvedett, amelyből sikeresen rehabilitálták, és járókerettel lassan, de biztonsággal tud járni, az állandó hólyagkatéter alkalmazása óta azonban csak nappal kontinens. A család azóta 24 órás felügyeletet szervezett a saját lakásában, egy szakképzett és két szakképzetlen gondozónő közremúködésével, akik mindenben segítik. Enyhe neurokognitív zavara (korábbi nevén dementia) mellett egy éve gyógyszermellékhatásként agitáltság, hallucinációk, 1-2 napig tartó 
insomnia, hányinger, collapsus lépett fel, ezért neurológusa a gyógyszerváltás mellett döntött. Napi l mg rasagilin tablettát írt fel, de két hónap elteltével ismét megjelentek a magatartászavarok, időnként agresszív a gondozónőkkel, éjszaka nem alszik, vetkőzik, menni akar, vigyázni kell rá. A 28 éve fennálló betegség 2012- 2015-ig tartó hároméves időszakának megfigyelési tapasztalatai alapján dolgoztuk ki modellünket, amelynek első lépéseként egy ápolási tervet állítottunk össze (3. táblázat), amellyel legfóbb célunk segítség nyújtása a családnak, gondozóknak az egyre nehezebb helyzetek megoldásában.

3. táblázat |Ápolási-gondozási terv

\begin{tabular}{|c|c|c|c|c|c|}
\hline & Ápolási diagnózis & Ápolási cél & Ápolási tevékenység & Orvosi utasítás & Eredmény értékelése \\
\hline 1. & $\begin{array}{l}\text { Reggeli nyelési nehezítettség, } \\
\text { hányinger, hányás. }\end{array}$ & Aspiráció elkerülése. & $\begin{array}{l}\text { Étkezés előtt hányáscsillapító } \\
\text { adása, szükség esetén } \\
\text { az étkezés felfüggesztése, } \\
\text { 1-2 óra elteltével óvatosan } \\
\text { megpróbálhat enni, } \\
\text { folyadékot kortyolgatni, } \\
\text { célszerü a gyógyszereket evés } \\
\text { közben beadni, szükség } \\
\text { esetén összetörni. }\end{array}$ & $\begin{array}{l}\text { Sze: } 10 \text { mg domperidon } \\
\text { tabletta étkezés előtt } \\
\text { beadva. } \\
\text { Étkezés közben nem } \\
\text { hagyható magára. }\end{array}$ & $\begin{array}{l}\text { Nem aspirált, } \\
\text { hányingere } \\
\text { megszûnt. }\end{array}$ \\
\hline 2. & $\begin{array}{l}\text { Állapotromlás veszélye } \\
\text { a gyógyszerbevételi nehézség, } \\
\text { illetve a betegség progressziója } \\
\text { következtében. }\end{array}$ & $\begin{array}{l}\text { A gyógyszer } \\
\text { bejuttatásának } \\
\text { biztosítása. }\end{array}$ & $\begin{array}{l}\text { Aspiráció elkerülése, a napi } \\
\text { gyógyszerek porrá tört } \\
\text { formában való beadása kevés } \\
\text { folyadékkal. }\end{array}$ & $\begin{array}{l}\text { Gyógyszerelés: } \\
\begin{array}{ll}1-0-0 & 10 \mathrm{mg} \text { selegrin } \\
1-1-0 & \text { Nitromint } 2,6 \mathrm{mg} \\
& \text { retard } \\
2-1-0 & \text { Cavinton }\end{array}\end{array}$ & $\begin{array}{l}\text { Gyógyszereit } \\
\text { megkapta, } \\
\text { állapotromlás } \\
\text { veszélye emiatt már } \\
\text { nem áll fenn. }\end{array}$ \\
\hline 3. & $\begin{array}{l}\text { Feszültség, agitáltság, } \\
\text { hallucinációk, álmatlanság } \\
\text { az anti-Parkinson- } \\
\text { gyógyszer mellékhatása } \\
\text { következményeként. }\end{array}$ & $\begin{array}{l}\text { A feszültség oldása, } \\
\text { a nyugodt fázis } \\
\text { elérése. }\end{array}$ & $\begin{array}{l}\text { A beteg biztatása, pszichés } \\
\text { támogatása, beszélgetés, } \\
\text { tájékoztatás valamennyi } \\
\text { ápolási múveletnél. }\end{array}$ & $\begin{array}{l}\text { Gyógyszerváltás: } \\
\text { 1-0-0 1 mg razagilin } \\
1-1-0 \quad \text { Nitromint } \\
\quad 2,6 \text { mg retard } \\
\text { 2-1-0 Cavinton } \\
\quad+ \\
2400 \text { mg Nootropil } \\
\text { granulátum } \\
0,5-1 \text { 1 folyadékban feloldva } \\
\text { napközben megitatni. } \\
\text { Csak végső esetben: } \\
\text { Antipszichotikum } \\
100 \text { mg quetiapin tabletta }\end{array}$ & $\begin{array}{l}\text { Pszichés állapota } \\
\text { stabilizálódott, } \\
\text { az éjszakát } \\
\text { átalussza. }\end{array}$ \\
\hline 4. & $\begin{array}{l}\text { Elesés- és sérülésveszély } \\
\text { a mozgáslabilitás miatt. }\end{array}$ & $\begin{array}{l}\text { A biztonságos } \\
\text { környezet és mozgás } \\
\text { megteremtése. }\end{array}$ & $\begin{array}{l}\text { Biztonságos környezet } \\
\text { kialakítása, fürdókád helyett } \\
\text { zuhanyozó kialakítása, } \\
\text { küszöbök, szőnyegek } \\
\text { felszedése, bútorok praktikus } \\
\text { elhelyezése, kapaszkodók } \\
\text { felszerelése. Napi ötszöri séta } \\
\text { járókerettel, gyógytornász } \\
\text { bevonásával } \\
\text { mozgáskoordinációt fejlesztő } \\
\text { gyakorlatok végzése. }\end{array}$ & Sérülésveszély elhárítása. & $\begin{array}{l}\text { A beteg nem sérült } \\
\text { meg. }\end{array}$ \\
\hline 5 . & $\begin{array}{l}\text { Csökkent önellátás a higiénia } \\
\text { terén, diszkomfort érzése. }\end{array}$ & $\begin{array}{l}\text { A beteg testi } \\
\text { higiénéjének } \\
\text { biztosítása, } \\
\text { a diszkomfortérzés } \\
\text { megszüntetése. }\end{array}$ & $\begin{array}{l}\text { Segédkezés a napi fürdésnél, } \\
\text { mosakodásnál, lehetőség } \\
\text { biztosítása a napi többszöri } \\
\text { tisztálkodásra. Az önállóság } \\
\text { megtartásának támogatása: } \\
\text { hagyjuk, hogy önállóan } \\
\text { végezze, amit tud, de ne } \\
\text { hagyjuk magára, fogmosásnál } \\
\text { fokozottan figyeljünk, } \\
\text { nehogy a vizes mosdó szélére } \\
\text { tegye a múfogsorát, ahonnan } \\
\text { könnyen belecsúszhat a } \\
\text { mosdókagylóba és eltörhet. } \\
\text { Folyamatosan dicsérjük } \\
\text { önállóságát, ügyességét. }\end{array}$ & Fokozott felügyelet. & $\begin{array}{l}\text { A beteg } \\
\text { diszkomfortérzése } \\
\text { megszúnt. }\end{array}$ \\
\hline
\end{tabular}




\section{A 3. táblázat folytatása}

\begin{tabular}{|c|c|c|c|c|c|}
\hline & Ápolási diagnózis & Ápolási cél & Ápolási tevékenység & Orvosi utasítás & Eredmény értékelése \\
\hline 6. & $\begin{array}{l}\text { Öltözködés nehezítettsége } \\
\text { a mozgáskoordináció zavara } \\
\text { miatt. }\end{array}$ & $\begin{array}{l}\text { Megfelelő száraz, } \\
\text { higiénikus ruházat } \\
\text { biztosítása. }\end{array}$ & $\begin{array}{l}\text { Az öltözködés segítése, } \\
\text { naponta tiszta ruha és tiszta } \\
\text { ágynemú, szükség esetén } \\
\text { ruha- és ágynemúcsere. }\end{array}$ & Mozgáskoordináció javítása. & $\begin{array}{l}\text { Komfortérzés } \\
\text { biztosított. }\end{array}$ \\
\hline 7. & $\begin{array}{l}\text { Csökkent önellátás a } \\
\text { táplálkozási szüksséglet } \\
\text { kielégítése terén. }\end{array}$ & $\begin{array}{l}\text { A megfelelő } \\
\text { folyadék- és } \\
\text { tápanyagbevitel } \\
\text { biztosítása. }\end{array}$ & $\begin{array}{l}\text { A megfelelő étrend kialakítása } \\
\text { dietetikus bevonásával, napi } \\
2-31 \text { folyadék (víz, tea, } \\
\text { üdítő, leves, turmix) orális } \\
\text { bevitelének biztosítása, } \\
\text { a cukros üdítők kerülése. } \\
\text { Változatos menü, sok } \\
\text { zöldség, gyümölcs kínálása. } \\
\text { A folyadékháztartás } \\
\text { egyensúlyban tartása, } \\
\text { a bevitt és ürített folyadék } \\
\text { dokumentálása. }\end{array}$ & $\begin{array}{l}\text { Vérkép, vércukor, } \\
\text { elekrolit-panel, } \\
\text { vesefunkciók időszakos } \\
\text { ellenőrzése. }\end{array}$ & $\begin{array}{l}\text { A homeosztazis } \\
\text { egyensúlyban van. }\end{array}$ \\
\hline 8. & $\begin{array}{l}\text { Megváltozott széklet- és } \\
\text { vizeletürítés, nem mindig érzi, } \\
\text { hogy ürítenie kell. }\end{array}$ & $\begin{array}{l}\text { A megfelelő higiénia } \\
\text { és a napi ritmus } \\
\text { biztosítása. }\end{array}$ & $\begin{array}{l}\text { Nappali nadrágpelenka } \\
\text { használata megelőzésként, } \\
\text { legalább két óránként } \\
\text { kikísérni, hogy kialakuljon } \\
\text { egy napi ritmus. Minden } \\
\text { alkalommal lemosás, } \\
\text { testápoló használata, } \\
\text { szükség szerint fürdés, ruha- } \\
\text { és ágynemúcsere elvégzése. } \\
\text { Éjszakára nagy nedvszívó } \\
\text { pelenka alkalmazása a } \\
\text { nyugodt alvás érdekében. }\end{array}$ & $\begin{array}{l}\text { Beteg fokozott } \\
\text { megfigyelése, mobilizációja. }\end{array}$ & $\begin{array}{l}\text { Száraz tiszta } \\
\text { ruházat és ágy } \\
\text { biztosított, } \\
\text { komfortérzet } \\
\text { megfeleló. }\end{array}$ \\
\hline 9. & $\begin{array}{l}\text { Decubitus kialakulásának } \\
\text { kockázata az inkontinencia és } \\
\text { az immobilitás következtében. }\end{array}$ & $\begin{array}{l}\text { A decubitus } \\
\text { elkerülése, megfelelő } \\
\text { mozgás biztosítása. }\end{array}$ & $\begin{array}{l}\text { Folyamatos hely- és } \\
\text { helyzetváltoztatás, gyakori } \\
\text { felkeltés a fotelból, rövid } \\
\text { séták a lakásban, gangon, } \\
\text { testmasszázs, fizioterapeuta } \\
\text { bevonásával speciális } \\
\text { tornaprogram kialakítása, } \\
\text { amelyet távollétében is képes } \\
\text { végezni a beteg. Mindig } \\
\text { száraz pelenka biztosítása, } \\
\text { rendszeres bórápolás, } \\
\text { antidecubitor eszközök } \\
\text { alkalmazása. }\end{array}$ & Decubitus-prevenció. & $\begin{array}{l}\text { A bőr integritása } \\
\text { megőrzött, } \\
\text { decubitus nem } \\
\text { alakult ki. }\end{array}$ \\
\hline 10. & $\begin{array}{l}\text { Obstipáció kialakulásának } \\
\text { kockázata. }\end{array}$ & $\begin{array}{l}\text { A bélpangás } \\
\text { elkerülése, rendszeres } \\
\text { székürítés biztosítása. }\end{array}$ & $\begin{array}{l}\text { Megfelelő táplálék- és } \\
\text { folyadékbevitel, könnyú, } \\
\text { présmentes széklet } \\
\text { biztosítása. Napi székürítés } \\
\text { ellenőrzése, naplóban történő } \\
\text { vezetése. }\end{array}$ & $\begin{array}{l}\text { Sze: I evő́kanál Laevolac } \\
\text { adása este. }\end{array}$ & $\begin{array}{l}\text { Nincs bélpangás, } \\
\text { a beteg naponta } \\
\text { vagy kétnaponta } \\
\text { ürít székletet. }\end{array}$ \\
\hline 11. & $\begin{array}{l}\text { Pneumonia kialakulásának } \\
\text { kockázata a mozgásszegénység } \\
\text { következtében. }\end{array}$ & Pneumonia kivédése. & $\begin{array}{l}\text { A beteg kiültetése } \\
\text { karosszékbe, többszöri } \\
\text { felültetése, ne legyen } \\
\text { lecsúszva, gyakori sétáltatása. } \\
\text { Mozgást segító tornaprogram } \\
\text { összeállítása gyógytornász } \\
\text { bevonásával, és légzőtorna, } \\
\text { hátmasszázs végzése. }\end{array}$ & $\begin{array}{l}\text { Beteg fokozott } \\
\text { megfigyelése, mobilizációja. }\end{array}$ & $\begin{array}{l}\text { Pneumonia nem } \\
\text { alakult ki. }\end{array}$ \\
\hline
\end{tabular}

Látható, hogy esetünkben nem csupán egy jól bevált standard gondozási folyamatról, hanem egy olyan komplex és a beteg állapotváltozásaihoz igazodó orvosi-ápolói-gondozói ellátás megszervezésérốl van szó, ami akár napi szintû́ kapcsolattartást igényel a neurológus szakorvossal és a háziorvossal, ezért az ápolástudományban már jól bevált ápolási tervet vettük alapul. Az ápolási diagnózisokat (beteg problémáit) prioritási sorrendben 
állítottuk fel, és olyan célokat tűztünk ki, amelyek a beteg problémáinak megoldását, csökkentését, segítését jelentik, majd a célok eléréséhez konkrét beavatkozásokat rendeltünk. Az egészségügyi team problémákra adott válaszait a gondozás szemszögéből fogalmaztuk meg, az összetartozó problémákat együtt kezeljük.

Probléma: Reggeli nyelési nehezítettség, hányinger, hányás. Állapotromlás veszélye a gyógyszerbevételi nehézség, illetve a betegség progressziója következtében

\section{Az ápolási-gondozási team problémamegoldó válasza}

A cél az aspiráció elkerülése és az állapotromlás megakadályozása. A nyelési nehézség oka a nyelésben részt vevó izmok gyengülése, amit tovább ront a beteg görnyedt testtartása, fejének lógatása, és betegünknél a mohó evés, amelynek következtében úgy tesz a szájába újabb és újabb falatokat, hogy még le sem nyelte az előzőt. Nagyon figyelni kell rá, biztatni a lassabb étkezésre, és megkérni az alapos rágásra. Nem hagyható magára! Az aspiráció elkerülését segíti elő az ételek pépesebb formában történő elkészítése, amely megkönnyíti a nyelést. Azonban a túl híg ital sem jó, dietetikusunk javasolta, hogy az italokat is enyhén sûrítsük be, például méz hozzáadásával, gyümölcsturmix készítésével, és a bő folyadékbevitelt segítsük elő a magas víztartalmú zöldségek és gyümölcsök fogyasztásával. A gyógytornász és a beszédterapeuta nagymértékben segítheti a helyes fejtartásra való átszoktatást, megfelelő gyakorlatokkal a nyeléshez szükséges izomzatot tudja edzeni, amelyet a koordinációs nyelvgyakorlatok tovább erősítenek. Az éneklés nemcsak a beteg hangulatát javítja, a torok területén található izmokat is igen hatékonyan edzi. Esetünkben ez nem jelent nehézséget, betegünk operetténekesi múlttal rendelkezik és gyakran énekelget fürdés közben is.

A hányingert kivédhetjük azzal, hogy a beteg étkezés közben veszi be az anti-Parkinson-gyógyszereket és naponta inkább többször eszik kis adagokat. Leghatásosabb gyógyszeres kezelés a domperidon dopaminreceptor-antagonista, amely perifériásan és a kemoreceptor trigger zónában, vagyis a vér-agy gát vér oldalán blokkolja a dopamin hatását. Mivel a vér-agy gáton alig jut át, elvileg a motoros múködést nem gátolja, bár mi $1 \times 10$ mg tabletta négy napon át történő adását követően határozott meglassulást észleltünk a beteg mozgásában.

Probléma: Feszültség, agitáltság, hallucinációk, álmatlanság az anti-Parkinson-gyógyszer mellékhatása következményeként

\section{Az ápolási-gondozási team problémamegoldó válasza}

Elsődleges cél a beteg nyugalmának mihamarabbi helyreállítása és fenntartása. Betegünknél a MAO-bénítók selegilin (Jumex), razagilin (Azilect) - olyan mellékhatásait figyelhettük meg, mint a lobbanékony viselkedés, hallucináció, zavartság, álmatlanság és a napszakok felcserélése. A megfigyelési időszak utóbbi egy évében szin- te átvették a vezetést ezek a káros mellékhatások okozta tünetek, ami több gondozó távozását is eredményezte. A legnagyobb problémát abban látjuk a nem szakképzett segítőknél, hogy személyes sértésnek veszik a beteg agresszivitását, és kudarcként élik meg a beteg engedetlenségét, ugyanis nem hiszik el, hogy a beteg nem tehet erről a viselkedésváltozásról. Ezért az edukációt tartjuk a legfontosabbnak, elsősorban a betegség természetének, tüneteinek, valamint a gyógyszermellékhatásoknak a megismertetését valamennyi ellátóval. Az álmatlansággal, sajnos, még nincs vége a tünetek sorának, a betegnél időnként pszichotikus látomások lépnek fel, személyeket lát a szobában, és a 2-3 napig tartó felfokozott idegállapot, valamint a kialvatlanság következményeként már annyira kifárad, hogy szinte állva elalszik, alig bír továbblépni, nem akar enni, inni, ugyanakkor lefeküdni sem. Ez valóban nagy és komplex probléma, de megfelelő attitüddel és határozott kommunikációval nem lehetetlen kibillenteni ebből az állapotból. Először is azt kell megérteni, hogy ez nem szándékos viselkedés a beteg részéről, másnap nem is emlékszik semmire, és állítja, hogy ő egész éjszaka aludt. Másodszor, bármennyire is szeretjük a beteget, ilyen állapotban már nem teljesíthetjük minden kívánságát, itt már határozottabb kommunikációra van szükség. Szerencsére betegünk mellett olyan tapasztalt szakképzett gondozónő van, aki jól ismeri a betegséget, ezáltal tudja kezelni a beteget, és van egy állandó civil segítőnk is, aki képes a helyzetnek megfelelő magatartásra, korábbi tapasztalataira támaszkodva tudja, hogy nem várhat normális reakciót egy pszichotikus betegtől, és bár tudományos magyarázatot nem találtunk rá, határozott fellépésével képes kizökkenteni és szófogadásra bírni a beteget. Türelmes és következetes magatartásával képes megállítani, igaz, hogy nem elsőre, de másodikharmadik próbálkozásra alvásra bírja a beteget minden kényszer és egyéb gyógyszer alkalmazása nélkül. Amenynyiben mégis szükséges lenne a kezelés, akkor nem szedatívumokat, hanem antipszichotikumokat kell alkalmazni, amelyek közül a quetiapin az első választandó szer, mert kevésbé rontja a motoros tüneteket. A demens betegek azonban nem igazán reagálnak a quetiapinra, a pszichózis leghatékonyabb gyógyszere a clozapin (agranulocytosis veszélye).

A Parkinson-betegek elég gyakran kerülnek kórházba az ilyen pszichotikus tünetek miatt, továbbá olyan problémákkal, mint az alvászavarok, motoros szövődmények, helytelen gyógyszerelés mellékhatásai, betegséggel öszszefüggő traumák, sérülések, pneumoniák és az alapbetegségtől független okok. Különösen akkor jelent ez problémát, ha a beteg nem neurológiai osztályra kerül, és a szakszemélyzet ismerethiánya miatt további szövődményeket kell elszenvednie. Ezért tartjuk fontosnak a bennfekvés során is a személyre szabott terápia kialakítását, a neurológusi konzílium kérését, az ápolók és az orvosok felkészítését a speciális feladatokra, a beteg szoros megfigyelésére [18]. 
Probléma: Elesés- és sérülésveszély a mozgáslabilitás miatt

Az ápolási-gondozási team problémamegoldó válasza

Biztonságos környezet kialakítása. A PK-betegek fokozott kockázata az elesés, ezért elsődleges cél az elesések és a sérülések megelőzése. Betegünk lakásában megszüntettük a küszöböket, felszedtük az összes szőnyeget, lábtörlőt a botlásveszély miatt. A járókeret mellett kapaszkodók felszerelésére nincs szükség, ugyanakkor különösen ügyelni kell, hogy leüléskor és felálláskor ne a járókeretbe kapaszkodjon, mert az könnyen felborulhat és a beteg hátraesik. Leüléskor engedje el a járókeretet, és a WC-ülókére vagy a fotel karfájára támaszkodjon, felálláskor ezekről nyomja fel magát, és csak állva fogja meg a járókeretet. Fontos, hogy ruházata ne akadjon be sehová, és a papucsa ne csússzon a padlón. Forgatókönyvet alakítottunk ki a helyiségek közötti legbiztonságosabb közlekedésre, amit megtanult a beteg, önállóan megy, fordul, nyitja az ajtókat anélkül, hogy elengedné a járókeretet, még a szűk fürdőszobába is bemegy egészen a mosdóig, zuhanyzóig. Csak figyelni kell, és nem szabad a fordulás irányán változtatni, mert az megzavarja. Nincs az útjában semmilyen tárgy, és mindig rend van körülötte, lépcsőn nem jár, csak a lakásban közlekedik. A gondozónők nem emelgetik, türelmesen kivárják, amíg magától elvégez mindent, hogy minél tovább megőrizze erejét.

Mozgáslabilitás kezelése mozgásterápiával. A mobilizálás és az erőnlét javítása elsősorban fizioterápiás módszerekkel, gyógytornával érhető el. Azok a fizioterápiás eljárások részesítendők előnyben, amelyek a beteg aktivitását igénylik. A foglalkoztató terápia alkalmas a funkciók célirányos gyakoroltatására, valamint a napi élettevékenységbe történő beillesztésére. A hagyományos gyógyszerek mellett kiegészítő terápiaként alkalmazhatunk masszázst, amely segíti az izmok ellazítását, valamint gyógynövényeket és akupunktúrát a nem motoros tünetek - depresszió, álmatlanság - kezelésében. Az egyensúly és a testtartás javítására bizonyítottan alkalmas a Thai Chi, a ritmusos és finom mozgások javítását szolgálja a mozgás- és bábterápia. Egyéb kiegészítő terápiák közé sorolhatjuk a múvészetterápiát, a reflexológiát, jógát, hidroterápiát, zeneterápiát (Kodály-módszer) és a hipnoterápiát. Kutatásokkal bizonyított tény, hogy valamennyi tünet enyhíthető a korán megkezdett mozgásterápiával, ezáltal lassítható a betegség progressziója. A neurorehabilitáció speciális módszere a '40-es években kidolgozott proprioceptív neuromuscularis facilitációs technika (PNF) érintési ingerekkel javítja a beteg stabilitását, koordinált mozgását, és nem utolsósorban növeli erejét. A streching - nyújtógyakorlat - az izommerevség feloldását szolgáló módszer, leginkább a relaxációs technikákhoz hasonlítható. A PK-betegek szédülése és elesése komoly veszélyforrás, ami a nyaki csigolyák melletti kisízületek helyzetérzékelésének romlására vezethető vissza. Ha feloldjuk ezen a területen az izomzat merevségét, jelentősen javul a beteg tartási rendellenessége [19].
Betegünk mozgásfunkcióját idős kora ellenére sikerült az önállóságig fejleszteni, a fej- és törzskontroll kialakításával megtanulta a kéz- és lábtámasz használatát, és az életkorának megfelelő hely-és helyzetváltoztatást. Megfigyeltük, hogy a felállás akkor sikeres, ha a két kezére és a lábára támaszkodik, és gyorsan egyenesedik fel. Ha mindezt lassan teszi, annyira remegni kezd a lába, hogy visszaesik a fotelbe. Azokra a mozgásokra helyeztük a hangsúlyt, amelyek a lakáson belül a járókerettel történő biztonságos közlekedést szolgálják.

Betegünket olyan fizioterapeuta kezelte, aki a Parkinson-mozgásterápiában kellő gyakorlattal rendelkezik, és már a combnyaktörést követően a kórházban megtanította a járókeret helyes használatára. Fontos szempontnak tartottuk, hogy az otthoni foglalkozásokat is ugyanaz a személy tartsa, aki már ismeri a beteg történetét, képességeit, akire hallgat és megszokta jelenlétét. Időskorban nagyon fontos, hogy a beteget az általa megszokott személyek vegyék körül, az idegenek és a folyamatos változás ugyanis kizökkenti a nyugalmából. Megfigyeltük, hogy még a saját családtagjaitól is zavart magatartás lép fel, ha már 2-3 személynél többen látogatják egyszerre. A fizioterapeuta kezdetben naponta járt a beteghez, és miután meggyőződött, hogy a beteg, a gondozók és a családtagok is elsajátították a gyakorlatok alkalmazását, fokozatosan csökkentette látogatásai számát. Bár a mozgásgyakorlatokkal a betegség korai fázisaiban lehet a leglátványosabb sikereket elérni, a betegség előrehaladottabb formájában a beteg önálló mozgásának fenntartására is sikeresen alkalmazható.

Probléma: Csökkent önellátás a higiénia terén, diszkomfortérzés. Öltözködés nehezítettsége a mozgáskoordináció zavara miatt. Csökkent önellátás a táplálkozási szükséglet kielégítése terén. Megváltozott széklet- és vizeletürítés, nem mindig érzi, hogy ürítenie kell. Decubitus kialakulásának kockázata az inkontinencia és az immobilitás következtében

Az ápolási-gondozási team problémamegoldó válasza

Időseknél a funkcionális aktivitás szintjének mérésére skandináv geriátriai professzorok a Barthel-indexet ajánlják [20], mi a szükségletek kielégítésének módjához és az ápolási igény megállapításához az önellátási szintek (4. táblázat) ápolástudományban jól bevált egységesített háromszintű pontrendszerét javasoljuk. Betegünk valamennyi tevékenységnél 5 pontra értékelhető, összesen 50 pontot ért el, ami azt jelenti, hogy nem hagyható magára, és bár önállóan közlekedik a járókeretével, mindenben segítségre szorul.

Tisztálkodás. Cél: a testi higiénia és a beteg komfortjának biztosítása. A tisztálkodáshoz alkalmazzunk megfelelő eszközöket (testápolás eszközei, pamuttextília és ágynemü, inkontinencia esetén alkalmazható pelenkanadrágok). Betegünket reggel és este a gondozónő a zuhanyzóban - ahová kapaszkodót szereltünk - gyors, határozott mozdulatokkal állva lefürdeti, megtörli, testápolóval bekeni, majd preventíve nappali pelenkanadrá- 
Értékelés: 100 pont, aki teljesen önellátó, független; 50 pont, aki felügyeletre vagy segítségre szorul; 0 pont, aki teljesen függő, mindent el kell végezni helyette

\begin{tabular}{|c|c|c|}
\hline \multirow[t]{3}{*}{ 1. Étkezés } & Képtelen önállóan étkezni & 0 \\
\hline & Segítségre szorul az ételek felvágásánál, a vaj felkenésénél, mindent oda kell készíteni neki & 5 \\
\hline & Független, önellátó (önállóan tálal, eszik, elmosogat) & 10 \\
\hline \multirow{3}{*}{$\begin{array}{l}\text { 2. Mozgásképesség az ágyból } \\
\text { a székbe és vissza }\end{array}$} & Képtelen önállóan felülni, ülni és felkelni az ágyból & 0 \\
\hline & Szóbeli és/vagy fizikai segítséggel tud felülni, felkelni az ágyból és átülni a székbe & 5 \\
\hline & Független, önellátó (ágyban önállóan felül, és átül a székbe) & 10 \\
\hline \multirow[t]{3}{*}{ 3. Tisztálkodás } & Képtelen önállóan tisztálkodni & 0 \\
\hline & $\begin{array}{l}\text { Segítségre szorul az arc-, haj-, fog- és körömápolásnál, borotválkozásnál (segédeszközök } \\
\text { rendelkezésre állnak) }\end{array}$ & 5 \\
\hline & Független, önellátó & 10 \\
\hline \multirow[t]{3}{*}{ 4. WC-használat } & Képtelen önállóan a WC használatára & 0 \\
\hline & Segítségre szorul, de van, amit önállóan el tud végezni & 5 \\
\hline & Önálló, független (ki tud menni, ruháját le tudja venni, meg tudja törölni magát, tud tisztálkodni) & 10 \\
\hline \multirow[t]{3}{*}{ 5. Fürdés } & Képtelen önállóan fürödni & 0 \\
\hline & Segítségre szorul, de van, amit önállóan el tud végezni & 5 \\
\hline & Önellátó, független (kádban fürdik vagy zuhanyozik) & 10 \\
\hline \multirow[t]{3}{*}{ 6. Mozgásképesség sík területen } & Képtelen önállóan közlekedni, immobilis vagy $<50 \mathrm{~m}$ & 0 \\
\hline & $\begin{array}{l}\text { Segédeszköz nélkül vagy segédeszközzel (kerekes szék/járókeret/bot) szóbeli és/vagy fizikai } \\
\text { segítséggel közlekedik, sarkoknál is }>50 \mathrm{~m}\end{array}$ & 5 \\
\hline & Önálló, független, képes önállóan >50 métert megtenni segédeszközzel vagy a nélkül & 10 \\
\hline \multirow[t]{3}{*}{ 7. Lépcsőn járás } & Képtelen önállóan felmenni/lemenni a lépcsőn & 0 \\
\hline & $\begin{array}{l}\text { Segítségre szorul (szóbeli és/vagy fizikai segítségre, vagy segédeszközre, szállítóeszközre van } \\
\text { szüksége) }\end{array}$ & 5 \\
\hline & Önálló, független (segítség nélkül jár és lépcsôzik) & 10 \\
\hline \multirow[t]{3}{*}{ 8. Öltözködés } & Képtelen önállóan öltözködni, dependens & 0 \\
\hline & Segítséggel boldogul (felöltözés, levetkőzés) & 5 \\
\hline & Önálló, független (gombolkozás, cipzár, füző stb.) & 10 \\
\hline \multirow[t]{3}{*}{ 9. Széklet } & Inkontinens vagy beöntésekre szorul, és képtelen ezt egyedül megoldani & 0 \\
\hline & Esetenként inkontinens & 5 \\
\hline & Kontinens & 10 \\
\hline \multirow[t]{3}{*}{ 10. Vizelet } & Inkontinens vagy katéterezésre szorul, és képtelen ezt egyedül megoldani & 0 \\
\hline & Esetenként inkontinens & 5 \\
\hline & Kontinens & 10 \\
\hline
\end{tabular}

Maximum 100 pont

got és ruhát ad rá. A fogmosáshoz segítséget igényel, és ügyelni kell, hogy a fogsorát a mosdókagylóba tegye, mert a csap széléről könnyen lecsúszhat és eltörhet, valamint nehogy erôs vízsugár alá tartsa, mert az könnyen kiverheti a kezéból. Ezenkívül szükséglet szerint kell fürdetni, az esetleges széklet- és vizeletszennyeződést azonnal le kell mosni a bőréről, nem elég a pelenka- és a ruhacsere. A nedves bőrt óvatosan kell szárazra törölni, nem szabad dörzsölni, inkább felitatni, mert az idős beteg bőre vékony, pergamenszerü, ezért sérülékeny, hamar felázik, és pillanatok alatt kialakul a hámhiány. Használjunk jó nedvszívó ruhát, fordítsunk különös gondot a hajlatok szárazon tartására, a beteg ágynemúje, ruhája mindig legyen tiszta, száraz és ráncmentes, a lepedőt mindig feszítsük ki [21].

Táplálkozás. Cél: a kiegyensúlyozott táplálkozás biztosítása, amelyet a víz, a fehérjék, a szénhidrátok, a zsírok, valamint a vitaminok és az ásványi anyagok (makroelemek és nyomelemek) egészséges arányával érhetünk el. Időskorban hangsúlyozottá válik a tápanyagokban gazdag ételek és a folyadékegyensúly fontossága, a speciális igények és a fizikai aktivitás szintjének figyelembevétele. 89 éves betegünknek a gyengébb aktivitás és a lelassult anyagcsere miatt kevesebb kalóriára, de ugyanannyi 
értékes tápanyagra van szüksége, mint korábban, amelyet napi 4-5 alkalommal történő étkezéssel valósítunk meg. Étteremből érkező, választott menüt fogyaszt, amit futárszolgálat szállít a lakásra. Mindig megterített asztalnál étkezik, amelyet könnyen letörölhető műanyag asztalterítő véd, az ölbe helyezett tálca ugyanis labilis, morzsák kerülhetnek a ruhájára, fotelbe, továbbá a mobilizáció tekintetében is hasznos az a mozgás, amíg kiér a szobából a konyhába, és a séta összeköthető a mellékhelyiség használatával, valamint az étkezés utáni fogmosással. Apró mérete miatt nem érnek le a lábai a földre, ezért egy kis dobogót helyeztünk a szék elé, amire kényelmesen felteheti a lábait, és mindkét könyökével támaszkodhat az asztalon. Önállóan étkezik, csak fel kell vágni az ételt falatokra, kitölteni az italt a bögréjébe és odakészíteni a gyógyszert, amelyet étkezés közben vesz be. A nyelési zavar miatt nem hagyható magára, egyébként is szereti, ha vele együtt étkeznek. A leves teljes kikanalazásában segít a gondozónő a tányér megdöntésével, a második fogás elfogyasztásához is inkább a kanál használatát részesíti előnyben, és annak ellenére, hogy a jobb keze gyengébb, végig azzal eszik. A bögrét két kézzel tartja, amit csak félig tölt meg a gondozónő, hogy elbírja, és ne öntse magára. Az étkezés meghatározott napirend szerint történik, és a három fó étkezés között a gondozónő olyan ételt készít számára, amit szeret. Ez lehet tojásrántotta, főtt tojás, felvágott, virsli, zöldség, gyümölcs, turmix, joghurt, sütemény, keksz, lekvár. Az italoknál is törekednek a változatosságra, hol teát, hol kávét, kakaót, gyümölcslevet iszik, de sokszor iszik sima vizet. Ne feledjük, hogy az idős ember szomjúságközpontja már kevésbé múködik, ne csak kérdezzük, hanem itassuk meg.

Öltözködés. A cél a beteg önállóságának megtartása. Találjuk meg a megfelelő testhelyzetet a különböző ruhadarabok felvételére. Ülve vagy fekve is feladhatjuk a betegre a nadrágot, zoknit és a cipőt. A finom mozgások nehézkessége miatt célszerú a cipzárak és gombok helyett tépőzárral vagy kapcsokkal ellátott ruhadarabokat használni, az ingek és blúzok helyett inkább pólót és pulóvert adni a betegre. Az elasztikus anyagból készült ruhadarabokat és cipőket könnyebb le- és felvenni, és a bebújós cipőnél elkerülhetjük a cipőfüzővel való bajlódást. Mindig sima felületen üljön a beteg, ne legyenek redők az anyagon, az izzadás elkerülésére tanácsos a légáteresztő pamut használata.

Megváltozott széklet- és vizeletürítés. A cél a nappali kontinens állapot elérése és megtartása. Betegünk nem mindig érzi az ürítés szükségletét, ezért kétóránként kikísérik a mellékhelyiségbe. Ez a rendszeresség előmozdítja a napi ritmus kialakítását. Törekedni kell a hólyag teljes kiürítésére, a megfelelő személyi higiéné biztosítására, a fertőzések megelőzésére és a bőr épségének megőrzésére. A mobilizáció fenntartása valamennyi szükséglet szempontjából fontos, a gondozónők ügyelnek a gyakori hely- és helyzetváltoztatásra. Ha lecsúszott a fotelben, azonnal megkérik, hogy tolja fel magát, és amikor kétóránként felállítják, sétával és tornával is öszszekötik a mellékhelyiség használatát. Tilos huzamosabb ideig a beteget 90 fokos ülő vagy oldalt fekvő helyzetben tartani, és a fizioterapeuta távollétében legalább háromszor meg kell tornáztatni a végtagokat naponta. A vizelet- és székletürítés helyes ritmusának kialakításához az immobilizációt minél előbb szüntessük meg, gondoskodjunk a beteg megfelelő táplálék- és folyadékbevitelérôl dietetikus bevonásával [21].

Fokozott bőrápolás, a tartós nyomásnak kitett bőrfelület keringésének javítása. Cél: a decubitus megelőzése, amelynek biztosításához nyomáscsökkentő eszközöket (például: speciális antidecubitor matracok, ágyak, ágyvédők, gyopár párnacsalád, ülőpárnák, báránybőr ágycipő) és a mobilizáció eszközeit használhatjuk. Ne feledjük, hogy betegünk kisebb megszakításokkal egész nap ül a fotelében feltett lábakkal, a nyomásnak és hatalmas nyíróerőnek kitett bőrfelületeken (farpofák külső és belső felülete egészen a végbélnyíláshoz közeli területig, könyök, sarok) igen hamar - akár két óra alatt! - megjelenhet a bőrpír vagy a II. stádiumra jellemző kékesvörös, sötétlila színű beszûrődés (szuffúzió), amelyet már csak egy perc választ el a bőr folytonosságának megszakadásától. Ezek a lila foltok a gyulladáscsökkentő kenőcsök alkalmazása mellett is hónapokig megmaradnak a beteg bőrén, ami azt bizonyítja, hogy elkéstünk az ápolással. A bőr integritásának megőrzése, vagyis a megelőzés a legcélravezetőbb megoldás. Ne várjuk meg a bőrpírt! Alkalmazzunk vérkeringést javító bedörzsöléseket egyénre szabottan, a kockázati tényezók figyelembevételével. Ha a bőr már nem ép, ne masszírozzuk, ne dörzsöljük, és az aszepszis szabályaira fokozottan ügyeljünk! Biztosítsunk optimális hőmérsékletet a beteg számára, ne feledjük, hogy az idős beteg fázékony, teste könnyen lehúl. Tudományosan bizonyított tény, hogy a preventív kenőcsök javítják a mikrocirkulációt, antiszeptikus és gyulladáscsökkentő hatásúak. Inkontinens beteg esetében egyesek a prevenció érdekében az állandó hólyagkatéter bevezetését preferálják, nos, mi ellenezzük az automatikus és ok nélküli alkalmazását, gondos ápolással a nyomási fekély többnyire megelőzhető. Természetesen ehhez megfelelő személyi és tárgyi feltételekre, kellő felelősségtudatra és nagyfokú empátiás készségre van szükség. Betegünk kiszolgáltatott helyzetben van, segítségre szorul valamennyi szükséglete kielégítésében, és sorsa a szakszemélyzet kezében van, amennyiben kétóránként kimegy a mellékhelyiségbe, az a mozgásteljesítményére és a kontinencia megtartására is pozitív hatást gyakorol. Az ápolás és kezelés során a pszichés támasz nyújtása és a dicséret kiváló motiváló erővel bír [21].

\section{Probléma: Obstipáció kialakulásának kockázata. Pneumonia kialakulásának kockázata a mozgássze- génység következtében}

Az ápolási-gondozási team problémamegoldó válasza

Cél: az obstipáció és a pneumonia elkerülése, amelyhez az immobilizáció megszüntetésén, a helyes életmód ki- 
alakításán, valamint a gyakori légzőtornán át vezet az út. A székrekedés nemcsak az alapbetegségből, hanem a helytelen életmódból és a pszichés problémákból is ered. Segíteni kell egy olyan életvitel kialakítását, amelyben nyugodt körülmények között, naponta többször étkezik keveset a beteg, kerüli azokat az ételeket, italokat (fekete tea, vörösbor, kakaótartalmú étel és ital), amelyek székrekedéshez vezetnek, ügyel a napi 2-3 liter folyadék elfogyasztására, és beépíti étrendjébe az aszalt gyümölcsöket, a búzacsírát, amelyek növelik a ballasztanyagok arányát a táplálékban. A mozgás fokozza a bél perisztaltikáját, és ha elegendő időt szán a székürítésre, kialakul egy napi ritmus. Az egészséges étrend kialakításában a dietetikus ajánlására azt az étkezési irányelvet követjük, amelyben egyetlen összetevőt sem túlzunk el, törekszünk a megfelelő rosttartalom-, vitamin-, ásványianyagés kalóriabevitelre. Az olajos magvak mindegyike többszörösen telítetlen zsírsavakat tartalmaz, a rostok (például bab, lencse, brokkoli, kelbimbó, kelkáposzta, körte, alma, sárgarépa, zabpehely, mandula) pedig segítik a vastagbél múködését, megkötik a rákkeltô anyagokat a belekben, és egyenletes felszívódásuknak köszönhetően megfelelő vércukorszintet biztosítanak. Betegünknek 2-3 naponta van széklete, az emésztés segítésére, a széklet képződésének szabályozására étrendjébe több gyümölcsöt, zöldséget, lekvárt, gyümölcslevet iktattunk és kerüljük a fehér lisztet. Amennyiben nem szereti a beteg vagy idegenkedik tőlük, belecsempészhetjük turmixba, pudingba, joghurtba, úgy szívesebben elfogyasztja. A fehérjetartalmú élelmiszerekről (például tej, hús) viszont tudni kell, hogy gátolja a levodopa felszívódását, ami a mozgásteljesítmény romlásához vezethet. A magas rosttartalmú készítmények és a bőséges folyadékfogyasztás a rendszeres, könnyü, présmentes széklet biztosításában játszanak fontos szerepet, továbbá ma már létezik a modern orvostudomány, a klasszikus természetgyógyászat és a komplementer medicina alapelveire épülő kezelés. A székrekedés holisztikus gyógymódjához a természetes alapanyagú szereket (például a keserűsós gyógyvizek, a szulfátion, a nátrium-glaubersós és a magnéziumtartalmú vizek, Mira, Hunyadi János, Ferenc József) kombinálhatjuk fizikoterápiával, továbbá mozgásterápiával és megfelelő táplálkozással. Stresszmentes élet nem létezik, a stresszt nem lehet elkerülni, viszont feldolgozni igen. A stresszhelyzetek feloldása a stress coping (megbirkózóképesség) kifejlesztésével, valamint pszichoterápiával érhető el.

\section{Dokumentáció}

Intézményi keretek között az ápolás-gondozás pontos és részletes dokumentálásának szigorú szakmai és jogi szabályai vannak. A beteg otthonában tevékenykedő nem szakképzett gondozóknak nem kötelező, de hasznos egy átadófüzet vezetése, amelyben minden, beteggel kapcsolatos esemény rögzítésre kerül. Ez a feljegyzés lehet egyszerüen elbeszélő, narratív, de történhet meghatározott szempontok szerint. A problémaorientált egészségügyi feljegyzés (problem-oriented medical record - POMR) az ápolási folyamat lépései mentén haladva lehetővé teszi a terv folyamatos értékelését, felülbírálatát, a szükséges módosítások azonnali végrehajtását, ezáltal biztosítja a beteg individualizált ellátását és az egészségügyi teamtagok közötti információáramlást [17].

A 89 éves beteg életébe történő bepillantás jól reprezentálja, hogy Parkinson-kórral élni mindennapos kihívást jelent. Problémáinak megoldására és az őt körülvevő team munkájának összefogására dolgoztuk ki a holisztikus megközelítésű bio-pszicho-szociális szükségletek individuális kielégítését szolgáló modellünket, amelynek égető szükségességét számtalan vizsgálat támasztja alá. A konkrét kooperatív problémamegoldási folyamat ismertetésével célunk megkönnyíteni a betegek és családtagjaik életét. A Parkinson ápolási-gondozási modell széles körben történő megismertetése felhívja a figyelmet arra, hogy mit tehetünk a lehető legjobb ellátás és kezelés érdekében.

\section{Köszönetnyilvánítás}

Öszinte köszönetünket fejezzük ki Dr. Deutsch Tibor professzor úrnak az anyag professzionális angol összefoglalójának elkészítéséért, és köszönettel tartozunk $D r$. Rácz Károly professzor úrnak, aki kezdetektől segített a kézirat formai követelményekhez történő igazításában.

Anyagi támogatás: A közlemény megírása, illetve a hozzá kapcsolódó kutatómunka anyagi támogatásban nem részesült.

Szerzôi munkamegosztás: Cs. M.: A téma szakirodalmi feltárása és feldolgozása, a célkitűzés, módszer meghatározása, a Parkinson ápolási-gondozási modell kidolgozása és a kézirat megszövegezése. M. S.: A modell lehetőségeinek megismertetése a $\mathrm{PhD}$ életminőség-kutatásban részt vevő vizsgálati mintával. K. É.: A szakirodalom feltárásában való közremúködés. D. Gy.: Tanácsadás a kutatáshoz és a tanulmány elkészítéséhez. A cikk végleges változatát valamennyi szerző elolvasta és jóváhagyta.

Érdekeltségek: A szerzőknek nincsenek érdekeltségeik. A kézirat Molnár Sándorné PhD-kutatásához kapcsolódik, amelynek témavezetője Dr. Domján Gyula.

\section{Irodalom}

[1] Bereczki, D.: The description of all four cardinal signs of Parkinson's disease in a Hungarian medical text published in 1690. Parkinsonism Relat. Disord., 2010, 16(4), 290-293.

[2] Kovács, N.: Parkinson's disease from the perspective of general practice. [A Parkinson-kór a gyakorló orvosok szemszögéból.] Lege Artis Med., 2014, 24(8-9), 406-414. [Hungarian]

[3] Hidasi, E.: The up-to-date approach of Parkinson's disease. [A Parkinson-kór modern szemlélete.] Lege Artis Med., 2010, 20(12), 825-829. [Hungarian] 
[4] Szirmai, I.: Neurology. [Neurológia.] Medicina Könyvkiadó, Budapest, 2011. [Hungarian]

[5] Professional guideline of the Board of Neurology and the Ministry of Health, 2013: Medical treatment of Parkinson's disease and parkinsonism. [A Neurológiai Szakmai Kollégium és az Egészségügyi Minisztérium szakmai irányelve, 2013: A Parkinson-kór és parkinsonismus gyógyszeres kezelése.] http://www. pharmindex-online.hu/tartalom/a-parkinson-kor-es-parkinsonismus- gyogyszeres-kezelese-0 [Hungarian]

[6] Derkinderen, P., Rouaud, T., Lebouvier, T., et al.: Parkinson's disease. The enteric nervous system involvement. Neurology, 2011, 77(19), 1761-1767.

[7] Braak, H., de Vos, R. A., Bobl, J., et al.: Gastric alpha-synuclein immunoreactive inclusions in Meissner's and Auerbach's plexuses in cases staged for Parkinson's disease-related brain pathology. Neurosci. Lett., 2006, 396(1), 67-72.

[8] Takáts, A.: Word Day of Parkinson's patients. Budapest, 11 April 2014. [A Parkinson-betegek világnapjára. Budapest, 2014. április 11.] http://www.elitmed.hu/ilam/agykutatas/a_parkinson_ betegek_vilagnapjara_12071/[Hungarian]

[9] Aschermann, Zs.: Diagnostic algorithm of Parkonson's disease. Novel classification of Parkinson's syndromes. [Parkinson-kór diagnosztikus algoritmusa, Parkinson-szindrómák újabb klinikai felosztása.] Pécsi Tudományegyetem, Neurológiai Klinika, Pécs, 2013. http://docplayer.hu/4388246-Parkinson-kor-diagnosztikus-algoritmusa-parkinson-szindomak-ujabb-klinikai-felosztasa-dr-aschermann-zsuzsanna-pte-neurologiai-klinika-2013-1127.html [Hungarian]

[10] Kovács, N., Balás, I., Llumiguano, C., et al.: Deep brain stimulation: a breakthrough in the treatment of movement disorders. [Mély agyi stimuláció: egy új perspektíva a mozgászavarok kezelésében.] Lege Artis Med., 2009, 19(2), 119-126. [Hungarian]

[11] Kovács, N.: Evidence-based treatment of Parkinson's disease. [A Parkinson-kór evidenciákon alapuló kezelése.] Orvostovábbképző Szemle, 2011, 18(Klnsz.), 11-17. [Hungarian]

[12] Aschermann, Z., Kovács, N., Komoly, S.: Continuous dopaminergic stimulation in Parkinson disease: possibilities in 2013. [Folyamatos dopaminerg stimuláció Parkinson-kórban: lehetőségek 2013-ban.] Ideggyogy. Sz., 2013, 66(5-6), 209-210. [Hungarian]
[13] Takáts, A., Nagy, H., Radics, P., et al.: Treatment possibilities in advanced Parkinson's disease. [Kezelési lehetőségek a Parkinsonkór előrehaladott stádiumában.] Ideggyogy. Sz., 2013, 66(1112), 365-371. [Hungarian]

[14] Klivényi, P., Vécsei, L.: Clinical studies with levodopa/carbidopa intestinal gel. [Levodopa/carbidopa intestinalis géllel végzett klinikai vizsgálatok.] Ideggyogy. Sz., 2014, 67(1-2), 5-8. [Hungarian]

[15] Kovács, N., Aschermann, Z., Ács, P., et al.: The impact of levodopa-carbidopa intestinal gel on health-related quality of life in Parkinson's disease. [Levodopa/carbidopa intestinalis gél kezelés hatása az életminőségre.] Ideggyogy. Sz., 2014, 67(7-8), 245250. [Hungarian]

[16] Kovács, N., Nagy, F., Janszky, J., et al.: Role of deep brain stimulation treatment of dyskinesia. [Mély agyi stimuláció szerepe a mozgászavarok kezelésében.] Magyar Orvos, 2011, 19(7-8), 32-34. [Hungarian]

[17] Oláh, $A$. (ed.): Nursing science textbook. [Az ápolástudomány tankönyve.] Medicina Könyvkiadó, Budapest, 2012. [Hungarian]

[18] Clinical problems in patients with Parkinson's disease treated in hospital. Data from a systematic survey. [Klinikai problémák kórházban kezelt Parkinson-betegek körében. Egy szisztematikus áttekintés adatai.] Orvostovábbképző Szemle online, 2015. augusztus 27. http://www.otszonline.hu/parkinson_mozaik/ cikk/klinikai_problemak_korhazban_kezelt_parkinson_ betegek_koreben [Hungarian]

[19] Let's intensify hope. Exercise for patients with Parkinson's disease. [Tápláljuk a reményt! A Parkinson-kór gyógytornája.] Várószoba，2013. 03. 04. http://www.varoszoba.hu/cikk/ taplaljuk_a_remenyt_a/ [Hungarian]

[20] Mahoney, F. I., Barthel, D. W.: Functional evaluation: The Barthel index. Maryland State Med. J., 1965, 14(2), 61-65.

[21] Székely, A., Hollós, S., Csóka, M.: Intensive care unit clinical basics. [Intenzív terápiás osztályok klinikai alapismeretei.] Semmelweis Egyetem Egészségtudományi Kar, Budapest, 2013. [Hungarian]

(Csóka Mária, Budapest, Vas u. 17., 1088 e-mail: csoka.maria@upcmail.hu)

Az Orvosi Hetilap egyes számai megvásárolhatók a Mediprint Orvosi Könyvesboltban.

Cím: Budapest V., Múzeum krt. 17. - Telefon: 317-4948 